\author{
Marcin Leźnicki* \\ Malina Barcikowska**
}

Toruń

\title{
Wokół zagadnienia sprzeciwu. Wstępne rozpoznanie tematu - typologia pojęcia - zakres oddziaływania
}

Człowiek, istota, która umie powiedzieć „,nie”

G. Böhme

Na początku w kilku słowach powinniśmy napomknąć, skąd wziął się pomysł na napisanie poniższego tekstu? I tu od razu zasadnicza uwaga: inspiracji do jego napisania było niewątpliwie więcej niż kilka. Przywołując jedynie najważniejsze, należy zauważyć, że na jego powstanie miały wpływ między innymi: zaangażowanie autorki w działalność organizacji pozarządowej Amnesty International i realizacja w jej ramach cyklu warsztatów poświęconych tematowi sprzeciwu, jako siły formującej i wyrażającej światopogląd jednostki, jak również służącej budowie zaangażowanych postaw społecznych, a wreszcie dyskusja podjęta nad rozdzielnymi kategoriami sprzeciwu i buntu, ich charakterem, zasadniczymi podobieństwami i różnicami, w tym między innymi dyskurs nad ujawnianiem się wspomnianych

* Dr Marcin Leźnicki - adiunkt w Zakładzie Filozofii Moralnej i Bioetyki w Instytucie Filozofii Uniwersytetu Mikołaja Kopernika w Toruniu.

** Mgr Malina Barcikowska - filozof, antropolog, krytyk sztuki, pracownik Centrum Sztuki Współczesnej w Toruniu. 
kategorii w sytuacjach granicznych życia ludzkiego czy też analiza zjawiska sprzeciwu w rozlicznych kontekstach praktycznych.

$\mathrm{Z}$ drugiej strony, namysł autora nad kategorią sprzeciwu, która jest obecna w rozlicznych opracowaniach badawczych, w tym książkach i artykułach, by wzmiankować o publikacjach Jasona Baera (który próbuje stworzyć ogólną teorię sprzeciwu, jako opozycji), Helgi Kragh (która podejmuje problem sprzeciwu naukowego jako katalizatora postępu/rozwoju wiedzy), Murayama Kona, Johnsona Davida i Ann Roseth (których interesuje zjawisko sprzeciwu psychologicznego, jako „regulatora” ludzkiej tożsamości), Alfreda Stepana (który pisze prace z zakresu sprzeciwu politycznego, na przykładzie opozycji demokratycznej), Jana Hoeksmana i Petera Hoffenara (którzy analizują zjawisko tak zwanego „sprzeciwu wczesnego”, odróżnialnego choćby od buntu). O sprzeciwie w kontekście religii nadmienia w swojej pracy Upomnienie o humanizm Robert Royal, który suponuje, że sprzeciw generuje sytuację konfliktu wartości i wykluczenia.

Dalszym impulsem, mającym niewątpliwy wpływ na pogłębienie studiów nad zjawiskiem sprzeciwu, były konferencje, w których braliśmy udział, jak również debaty oraz spotkania naukowe poświęcone bliższej eksplikacji zagadnienia sprzeciwu, jak między innymi w przypadku moderowanej przez Johna Uhra konferencji The Power of Opposition. Political Theory of Opposition ${ }^{1}$.

Wychodząc od praktycznych, jak też teoretycznych inspiracji, w prezentowanym tekście podjęto wyłącznie próbę rozważenia sprzeciwu jako istotowo ważnego czynnika budującego tożsamość człowieka.

Za swoiste motto, leżące u podstaw omawianej w tekście kwestii sprzeciwu, posłużyły nam tymczasem słowa Gernota Böhmego, który w powziętej analizie naukowej z pogranicza antropologii filozoficznej jednoznacznie podkreśla, że „...człowiek to również istota, która umie powiedzieć „nie"2. W ramach poniższej pracy traktujemy wzmiankowany cytat jako myśl przewodnią, którą próbujemy zobrazować poprzez odniesienie jej do konkretnej koncepcji filozoficznej, opisującej tożsamość jednostki ludzkiej.

${ }^{1}$ Całość konferencji została zamieszczona na stronach internetowych, m.in. na platformie cyfrowej YouTube.

${ }^{2}$ G. Böhme, Antropologa filozoficzna, Warszawa 1998, s. 253. Wszelkie pogrubienia występujące w tekście są autorskie i służą lepszej jego eksplikacji. 


\section{Cel, tezy, założenia i uwagi wstępne}

Jako wstępną tezę prezentacji problemu sprzeciwu przyjęliśmy w tym tekście założenie, że możliwość sprzeciwu objawia się na każdej płaszczyźnie bycia czlowieka.

Aby dowieść jej zasadności, przyjmujemy założenie pochodzące z pracy Jerzego Perzanowskiego, który zauważa, że:

[C]złowiek [...] jest istotą krawędziową, ulokowaną jakby na przecięciu co najmniej czterech płaszczyzn bytowych. Płaszczyzny rzeczy i procesów naturalnych. $Z$ tą wiąże nas przede wszystkim ciało. Płaszczyzny przeżyć psychicznych - nie tylko spostrzeżeń, lecz także (subiektywnie ujętych) pojęć, myśli, wyobrażeń, uczuć i rozmaitych fantazmatów, które przenoszą nas poza sferę przyziemności. Płaszczyznę ich obiektywnych odpowiedników, czyli sferę idei, własności, pojęć i innych obiektów ogólnych wraz z płaszczyzną ich ekstensji (czyli mnogości, zbiorów, agregatów, etc.). A także płaszczyznę instytucji społecznych i kulturowych [...]. Przynajmniej niektórzy ludzie obcują też z płaszczyznami innymi, w tym z płaszczyzną ducha, przejawiającą się w życiu duchowym ludzi ${ }^{3}$.

Chcemy poczynić także uwagę wstępną, dotyczącą analizowanych pojęć. Warto zauważyć, że interesujący nas termin „sprzeciwiać się” posiada liczne określenia bliskoznaczne. Według Stownika wyrazów bliskoznacznych są to między innymi: opierać się, przeciwstawiać się, wzbraniać się, wzdrygać się, uchylać się, odmawiać, nie godzić się, być w opozycji, występować przeciw czemuś, robić na przekór, płynąć przeciw fali, protestować, oponować, występować z protestem czy choćby zgłaszać sprzeciw. Słowa te, traktowane w języku potocznym jako „inne określenia tego samego”, tracą jednak bezpowrotnie swoją synonimiczność, jeśli wyjdziemy poza język potoczny i przejdziemy w bardziej precyzyjną dziedzinę pojęć filozofii.

Wstępne rozpoznanie tematu wskazuje na to, że można próbować przypisać każdej ze wspomnianych płaszczyzn bytowych określone terminy, które charakteryzują sprzeciw w jego odmiennej postaci, to jest

3 J. Perzanowski, O filozofii, http://www.tezeusz.pl/cms/tz/fileadmin/_temp_/Compiz/ compiz1/O_Filozofii.pdf. Zaproponowana przez J. Perzanowskiego typologia płaszczyzn bytowych jest autorska i wykorzystana zostanie w tekście bez jakichkolwiek modyfikacji, korekt czy ewentualnych zmian. 
w odniesieniu do każdej z nich. Próba wskazania pojęć adekwatnych dla każdego z wymienionych obszarów egzystencji jest także zadaniem, jakie postawiliśmy przed sobą do rozpoznania $\mathrm{w}$ ramach poniższego tekstu.

\section{Plaszczyzna pierwsza - rzeczy i procesów naturalnych}

Podejmując się próby omówienia zagadnienia sprzeciwu na płaszczyźnie rzeczy i procesów naturalnych, z którą wiąże nas zasadniczo ciało, powinniśmy postawić zasadne pytania o to, w jaki sposób możliwy jest sprzeciw cielesny?, czy też zaprzeczenie istnieniu cielesnemu (poprzez ciało)?, czy wreszcie negacja ciała (cielesności) ${ }^{4}$, która doprowadzona do skrajności będzie wieńczyć kres naszego (biologicznego) istnienia. Najdobitniejszą formą tego typu sprzeciwu, sprzeciwu wobec życia czy też rezygnacji z życia, będzie niewątpliwie samobójstwo ${ }^{5}$, które można analizować na co najmniej kilku płaszczyznach.

$\mathrm{Na}$ wstępie należy zauważyć, że samobójstwo (łac. suicidium) to akt celowego i świadomego odebrania sobie życia, do którego dochodzi w następstwie zaprzeczenia (własnej) egzystencji. Sama zaś sytuacja, w której dochodzi do aktu samobójczego, jest trudna do określenia, gdyż składa się na nią szereg czynników natury psychologicznej, bądź też/oraz społecznej, co z kolei, jak zauważa między innymi Zbigniew Szawarski, przekłada się

${ }^{4} \mathrm{~W}$ ramach literatury przedmiotu wzmiankowane terminy są traktowane zamiennie.

${ }^{5}$ Idąc za J. Perzanowskim, sprzeciw wyrażany na płaszczyźnie rzeczy i procesów naturalnych zakłada podjęcie wszelkich możliwych, a jednocześnie akceptowalnych przez daną jednostkę ludzką działań, tj. działań zgodnych z jej przekonaniami czy światopoglądem, zmierzających do definitywnego przerwania procesu jej naturalnego trwania (tj. życia) $\mathrm{w}$ akcie rzeczonego samobójstwa. Napomknąć przy tym należy, że wśród innych przykładów sprzeciwu wyrażanego na płaszczyźnie rzeczy i procesów naturalnych wskazuje się m.in. na głodówkę, akty samookaleczenia czy choćby „próby samobójcze”. Te jednak nie muszą i zazwyczaj nie wiążą się z ostatecznym zerwaniem procesów życiowych, lecz co najwyżej z ich destabilizacją, a tym samym zakres ich społecznego oddziaływania bywa zazwyczaj dużo słabszy. Jednocześnie należy zauważyć, że samobójstwo będzie potępiane między innymi przez przedstawicieli personalizmu chrześcijańskiego. Ci bowiem twierdzić będą, że człowiek otrzymuje życie w darze od Stwórcy i wyłącznie Bóg może je nam odebrać. Człowiek wobec powyższego pozostaje tylko i wyłącznie depozytariuszem swojego życia, nie zaś jego właścicielem, a tym samym akt samobójczy bezpośrednio uderza w Boga, deprecjonując jego rolę oraz znaczenie i rozpatrywany będzie w kategoriach grzechu ciężkiego (co jednoznacznie wyszczególnione zostało w ramach piątego przykazania, które swoim zasięgiem obejmuje nie tylko zabicie drugiego człowieka, ale też dyskutowany w tekście akt samounicestwienia). 
na złożoną typologię samobójstw. Podstawową trudność nastręcza jednak uproszczona charakterystyka tak zwanej sytuacji samobójczej, która w rozpowszechnionym rozumieniu staje się wyłącznie udziałem jednostek autodestrukcyjnych, ludzi z zaburzeniami sub/depresyjnymi, urazami psychicznymi spowodowanymi traumą, manią bądź zaburzeniami osobowościowymi (by przywołać przykład adolescencyjnych zachowań samobójczych) nie zaś jednostek, które są pozbawione powyższych dysfunkcji. Na wspomnianą trudność zwraca uwagę między innymi Émile Durkheim w pracy Samobójstwo. Analizując przyczyny samobójstwa, Durkheim zauważa, że akt samobójstwa wynika częstokroć z niezgody/sprzeciwu wobec pogłębiającej się dysproporcji społecznej, dezintegracji życia społecznego bądź anomii (tj. stanu niepewności i niezgody w systemie aksjonormatywnym spowodowanym najczęściej, choć nie wyłącznie, społeczną transformacją). Sprzeciw wobec zachodzących zmian przejawiający się w akcie samobójstwa może stać się jednak udziałem w równym stopniu osób zdrowych, jak i psychofizycznie zaburzonych. Jeszcze wyraźniej na korelację samobójstwa z szeroko rozumianą sferą działań społecznych zwraca uwagę Robert K. Merton, który konstatuje, że akt samobójstwa (w ramach powyżej przywołanej anomii) należy wiązać z niemożnością realizacji celów bądź też wartości pożądanych przez społeczeństwo za pomocą społecznie akceptowanych środków czy też norm. Na wspomnianą trudność zwraca również uwagę Takeshi Youmi, opisując samobójcze postawy Japończyków, niezdolnych do realizacji stawianych przed nimi kolejnych „przyśpieszonych zadan”” (by skorzystać $z$ terminologii Thomasa H. Eriksena), przy jednoczesnym ograniczeniu społeczeństwa kostyczną tradycją. $Z$ drugiej jednakże strony samobójcze akty sprzeciwu występowały już w starożytności, choć w znaczeniu odmiennym od konceptu Mertona. Między innymi John M. Rist podkreśla, że „w starożytności klasycznej samobójstwo było zjawiskiem nie tylko zwykłym, ale akceptowanym i w wielu przypadkach usprawiedliwionym", rzadko zaś potępianym ${ }^{6}$. Dla myślicieli doby starożytnej samobójstwo było bowiem jednym ze świadectw na to, że pewne dobra uznać należałoby za wyższe od cielesnego życia, by przywołać choćby wartość wolności czy samostanowienia. Myśliciele Ci zakładali tym samym, że niezależnie od jakichkolwiek zewnętrznych kryteriów odniesienia egzystencjalnego dla naszego życia w określonych sytuacjach samobójstwo będzie aktem nie tylko dopuszczalnym, ale wręcz wskazanym, jako że stanowiącym wyraz ludzkiej wolności,

6 J. M. Rist, Morality and Religion. Some Questions about First Principles, „Philosophical Investigations" 34 (2011), p. 218. 
u rudymentów której sytuował się postulat dobrowolności wyboru śmierci, jako „świadomego opowiedzenia się po stronie jakiegoś dobra w sytuacji, gdy konsekwencją takiego wyboru jest śmierć". Wielu myślicieli doby starożytnej podkreślało tym samym, że samobójstwo jest po prostu jednym $\mathrm{z}$ fundamentalnych świadectw na to, że pewne dobra (niematerialne) uznaje się za wyższe od cielesnego życia. Przykładowo w Platońskim Fedonie czytamy, że ,[D]opóki mamy ciało, a dusza nasza połączona jest z tak wielkim złem, nie zdobędziemy w dostatecznym stopniu tego, czego pragniemy"7. Odebranie sobie życia traktować można było tym samym jako najprostsze rozwiązanie ograniczeń narzuconych człowiekowi przez doczesność (o charakterze fizykocielesnym) oraz narzuconą przez bogów konieczność, to jest ananke. Przykładem tej ostatniej ${ }^{8}$ mógł być orzeczony przez państwo wyrok, któremu poddany został choćby Sokrates, nieograniczone nieszczęście (np. choroba) czy uniemożliwiająca dalszą egzystencję hańba. Wszystkie z powyższych domagały się relegacji, którą gwarantowało samobójstwo jako akt sprzeciwu wobec kary, choroby czy wreszcie hańby. Samobójstwo uznawane było zatem za przejaw ludzkiego uduchowienia i rozumności czy wreszcie cnotliwości. Tym niemniej w innym miejscu wspomniany Platon podkreśla9 ${ }^{9}$ że samobójstwo stanowi występek przeciwko bogom i państwu, którym to sprzeciwiamy się $\mathrm{w}$ akcie unicestwienia. To z kolei prowadzi Platona do postulowania wprowadzenia zakazu samobójstwa i zalecenia realizacji zadań, które postawili nam bogowie, po drugie zaś poszanowania prymatu Państwa, z którym los nas związał. To ostatnie podkreślać będzie także Arystoteles.

Wychodząc od powziętych powyżej analiz, choć w zarysie przedstawionych, przejść można w obszar nam czasowo bliższy i zadać pytanie, jak współcześnie interpretowane jest zjawisko sprzeciwu przejawiającego się w akcie samobójczym oraz zadać pytanie, czy zachodzą, a jeżeli tak, to jakie, korelacje myśli starożytnych badaczy z aktualnie wyrażanymi poglądami na temat „sprzeciwu samobójczego”.

Współcześnie zjawisko sprzeciwu analizuje się zasadniczo na płaszczyźnie socjobiologicznej oraz bioetycznej. O ile jednak w przypadku tej pierwszej akt sprzeciwu wiązać będziemy z jednostkową rezygnacją z życia na rzecz przetrwania większej całości (tj. gatunku czy też populacji), o tyle w przypadku rozstrzygnięć bioetycznych dyskutować będziemy zjawisko sprzeciwu pod kątem li tylko rezygnacji z życia obciążonego dysfunk-

\footnotetext{
7 Platon, Fedon, thum. W. Witwicki, Warszawa 1984, 66b.

${ }^{8}$ Por. tenże, Prawa, thum. M. Maykowska, Warszawa 1960, 873c-d; tenże, Fedon, 62c.

9 Tamże.
} 
cją psychofizyczną jednostki, która sprzeciwia się żyć życiem obciążonym zdrowotnie i traktuje je jako życie niewarte życia. W ujęciu bioetycznym będziemy zatem rozpoznawać sprzeciw w akcie odrzucenia życia obciążonego chorobą, życia dysfunkcyjnego i niezdatnego do korekcji biomedycznej. Sprzeciw taki, jak dodają zwolennicy bioetyk utylitarystycznych, występować zaś może zarówno pod postacią aktywna, w akcie samobójstwa, samobójstwa wspomaganego, bądź też eutanazji czynnej (dobrowolnej), jak i bierna/pasywna, kiedy to człowiek obciążony chorobą stopniowo z życia rezygnuje, sprzeciwiając się jego dalszemu trwaniu. Nie przyjmuje więc pokarmów i poddaje się ostatecznie eutanazji biernej. Drugi wariant sprzeciwu wobec życia, to jest sprzeciw bierny/pasywny, akceptowalny będzie jednocześnie dla zwolenników optyki personalistycznej w bioetyce. Uważają oni bowiem, że o ile samobójstwo oraz samobójstwo wspomagane, jak też wspomniana powyżej eutanazja czynna stanowią przykłady aktywnego procesu samounicestwiania się jednostki ludzkiej, o tyle eutanazja bierna ma charakter pasywny, to jest nieinterwencyjny i jako taka może być dopuszczana, przez bio/etyki wyznaniowe (w tym także akcentujący prajopawesa hinduizm [tj. głodówkę prowadzącą do śmierci], dżinijską santharę czy praktykowaną przez mahajanistów sokushinbuts). Różnica w podejściu bioetycznym do kwestii samobójstwa, jako formy sprzeciwu wobec życia, będzie się tym samym zasadniczo sprowadzać do postawionego między innymi przez Platona pytania o to, czy człowiek może przeciwstawić się ,życiu niewartemu życia" z jakichś powodów, co postulują utylitaryści, i odgórnej niemożliwości przeciwstawienia się choćby i obciążonemu biopsychicznie życiu, co postulują personaliści chrześcijańscy, głosząc przy tym, że sprzeciw wobec życia tożsamy jest ze sprzeciwem wobec Stwórcy całego istnienia, w tym też życia, które akt samobójczy niweluje i deprecjonuje. Pierwsi ze wspomnianych postulować będą tym samym wyjściowy prymat jakości życia, drudzy z kolei głosić będą przyrodzoną świętość życia samego w sobie, tożsamą $\mathrm{z}$ jego absolutną nietykalnością.

Co zaś się tyczy rozstrzygnięć socjobiologicznych w kontekście analizy zjawiska sprzeciwu, to zauważyć należy, że szukając biologicznych podstaw zachowań społecznych zwierząt, w tym także ludzi, socjobiolodzy, w tym John Haldane (w latach 50.), William D. Hamilton (na przełomie 1964 i 1965 roku), Edward O. Wilson w 1975 r. (m.in. w pracy badawczej Socjobiologia. Nowa synteza), czy choćby Richard Dawkins w latach 1981-1995 (m.in. w pracach Samolubny gen, Rozszerzony Fenotyp. Gen jako jednostka doboru, Ślepy zegarmistrz i Rzeka genów) zauważyli, że zachowania altruistyczne zwierząt, w sytuacji kiedy osobnik ryzykuje życie lub je poświęca 
na rzecz cudzego interesu, wynikają z bezpośredniej potrzeby utrzymania danego gatunku biologicznego w trwaniu. Dające się zaobserwować w przyrodzie zachowania altruistyczne, o ile są trudne czy wręcz niemożliwe do wytłumaczenia na gruncie klasycznego darwinizmu, gdyż nie ułatwiają, lecz utrudniają przeżycie i rozród osobnika altruistycznego, zostały poddane próbie wyjaśnienia między innymi przez Vitusa B. Dröschera (w odniesieniu do organizmów prostych), a także Vero C. Wynne-Edwardsa oraz Konrada Lorenza, propagatora teorii doboru grupowego, według której fundamentalnym kryterium doboru naturalnego może być i częstokroć nie jest tylko i wyłącznie interes poszczególnych osobników danego gatunku biologicznego, ale większe prawdopodobieństwo przeżycia całej populacji czy gatunku (tj. pomyślności danej grupy). Warto przy tym dodać, że wspomniana teoria na gruncie socjobiologii zastapiona została z czasem teoria doboru krewniaczego, a przyjmujący ją jak również zakładający altruizm zwrotny socjobiolodzy, zaczęli zauważać, że rezygnacja przez jednostkę biologiczną z życia, bądź zaprzeczenie własnej egzystencji przez dany organizm, nie stanowi formy przypadkowej aberracji, ale jest spotykanym w przyrodzie zjawiskiem, które ma na celu lepszą ekspansję genotypu danego gatunku biologicznego w określonej grupie krewniaczej, przez co zwiększa się samoczynnie potencjał rozwojowy tejże grupy.

\section{Płaszczyzna druga - przeżyć psychicznych}

Sprzeciw, jak podkreślają różne teorie psychologiczne, posiada fundamentalne znaczenie dla rozwoju jednostki. Zarysowując pole badań związane ze sprzeciwem, należy wymienić ${ }^{10}$ : teorie psychodynamiczne i psychoanalityczne (w tym koncepcje Zygmunta Freuda, Erika Eriksona oraz Carla Gustawa Junga), teorie poznawcze (Jeana Piageta), teorie uczenia się (behawioryzm), podejście humanistyczne (Abrahama Maslowa) czy wreszcie teorię etologiczną badającą zachowania tak ludzi, jak i zwierząt w środowisku naturalnym.

${ }^{10}$ Charakterystyki zjawiska sprzeciwu na dyskutowanej płaszczyźnie dokonano m.in. na podstawie artykułu J. Stacherzak-Raczkowskiej, Znaczenie sprzeciwu dla rozwoju jednostki z perspektywy wybranych teorii psychologicznych, w: B. Płonka-Syroka, J. Stacherzak-Raczkowska (red.), Motywy i formy sprzeciwu w świecie nowoczesnym i ponowoczesnym. Analiza Kulturowa, Wrocław 2010. 
Pojęcia zarówno sprzeciwu, buntu, rewolucji, jak też eskapizmu, mogą być odniesione do sprzeciwu opisywanego przez te teorie na różnych obszarach życia człowieka. Jak pisze Justyna Stacherzak-Raczkowska: „po części każde z nich można odnaleźć w rozważaniach przywoływanych psychologów" "11. Sprzeciw traktuje się tu podobnie jak w prezentowanej publikacji (tj. jako niezgodę czy protest), rozumie się go pokrewnie do terminu „bunt”. Według przywoływanego źródłosłowu, mówiąc o rewolucji, stosuje się tu odwołania do gwałtownej zmiany, także takiej, która może zajść w organizmie człowieka, natomiast terminu „eskapizm” (z angielskiego escape uchodzić, wymykać się) używa się na określenie sytuacji, w której jednostka unika problemów związanych z życiem społecznym.

Ta krótka uwaga dotycząca stosowanych w teoriach psychologicznych pojęć wyznacza $\mathrm{w}$ pewnej mierze również pole problemowe, w którym poruszają się psychologowie badający zjawisko sprzeciwu, by przywołać problem ciagłości lub stadialności rozwoju, zachowania kryzysowego wraz z kwestią pomocy podczas ich przechodzenia oraz kazus tak zwanego oderwania się od rzeczywistości.

Zgodnie z literaturą przedmiotu można wyróżnić dwa główne stanowiska teoretyczne dotyczące zagadnienia sprzeciwu. Pierwsze, nazwane biologicznym, określa sprzeciw jako zachowanie zakorzenione w czynnikach natury wrodzonej. Jego zwolennicy chętnie czerpią z dziedzictwa Hegla, mówiąc o systemach opartych na zasadzie biegunowości, a także filozofii idealistycznej, która zakłada, że podmiotowe przeżycia psychiczne są uzależnione od uwarunkowań ponadpodmiotowych, których przekroczenie jest dla człowieka niemożliwe. Drugie podejście głosi, że organizm nie determinuje zachowań, znaczącą rolę mają jednak uwarunkowania kulturowe (tzw. podejście społeczne).

Jak stwierdzono, sprzeciw towarzyszy nam od początku życia. Poprzez płacz noworodka (pierwsza ekspresja emocjonalna), „bunt dwulatka” (który jest pierwszą podejmowaną przez człowieka walką o niezależność i ściśle wiąże się z odkryciem używania słowa „nie”), okres dojrzewania - tak zwany bunt młodzieńczy (polegający na odkrywaniu własnej tożsamości, co z kolei ściśle łączy się chaosem, zamieszaniem i przemieszaniem ról czas ten określany jest często metaforycznie, jako czas „burzy i naporu”). Dostrzega się także elementy buntu w rozwoju dorosłego człowieka: wiek 28-33 lata (przejście w lata trzydzieste), wiek 40-45 lat (przejście w lata pięćdziesiąte), tak zwany „kryzys wieku średniego” (bunt przeciw starze-

11 Tamże, s. 22. 
niu się). Okresy te charakteryzuje kryzys łączony z momentami kwestionowania, wyboru i zmiany. Przyjmuje się, że są to przemiany uniwersalne, niezależne od kultury, do której się przynależy. Można w związku z tym mówić o tak zwanej naturalności kryzysów. Oddziela się je do buntu, sprzeciwu czy ucieczki, rozumianej jako sytuacja choroby.

Wydaje się, że w odniesieniu do płaszczyzny przeżyć psychicznych nagłośnioną dziś praktyczną formę realizacji sprzeciwu stanowi tak zwana asertywność. Jest ona przedmiotem licznych opracowań i treścią popularnych poradników psychologicznych. Już same tytuły niektórych z nich, jak np.: „trening asertywności”, „być asertywnym”. ,jak doskonalić asertywność” czy wreszcie „asertywność menedżera”, ukazuja, że traktuje się ją jako istotną umiejętność, którą można nabywać oraz doskonalić. Jak bardzo wydaje się ona niezbędna w codziennym życiu każdego z nas próbują przekonywać np. testy psychologiczne, dzięki którym można stworzyć specyficzną, prywatną „mapę asertywności”, czy wytyczne pod tak zwany „trening asertywności” zawierający różnorakie techniki terapeutyczne, które brak tej (tj. wybranej) cechy traktują jako zaburzenie, któremu należy przeciwdziałać. Umiejętność sprzeciwu staje się wobec powyższego praktyczną umiejętnością, umożliwiającą każdemu z nas budowanie prawidłowych relacji społecznych.

Bycie osobą asertywną wydaje się pożądanym wzorem, idealnym modelem typu człowieka, niezbędnym zarówno w sferze prywatnej, jak i publicznej. Tak podstawowe wartości, jak na przykład korzystanie z osobistych praw bez naruszania praw innych, postawa akceptacji oraz szacunku wobec siebie i innych, swobodne wyrażanie swoich pragnień, myśli, jak też uczuć, realizują się w byciu asertywnym. Parafrazując znaną definicję wolności, można powiedzieć, że „bycie asertywnym jest dziś praktyczną realizacją „bycia wolnym”, gdzie wolność polegałaby na poszanowaniu drugiego człowieka, w jego wolności, którą nasza wolność mogłaby naruszyć”.

\section{Plaszczyzna trzecia - obiektywnych odpowiedników}

Odwołując się do sprzeciwu, przynależnego płaszczyźnie pojęć, trzeba wspomnieć przede wszystkim występującą w języku logiki negację, którą odczytuje się przy użyciu zwrotu „nieprawda, że” lub, jeśli takie sformułowanie wywołuje nieporozumienia, używając w to miejsce słowa „nie" lub „nie jest tak, że”. Negacja jest zaliczana do języka logiki zdań i nosi nazwę spójnika międzyzdaniowego (ponieważ pełni funkcję podobną do pozosta- 
łych, tj. lub, i, jeżeli... to, wtedy i tylko wtedy), choć w sensie gramatycznym nie jest ona spójnikiem. Rozumiemy ją następująco: ,gdy jakieś zdanie p jest prawdziwe (czyli ma wartość logiczną 1), to negacja, tzn. ๆp jest fałszywe (czyli ma wartość logiczną 0)".

Przyjmuje się, że ten, podobnie jak i pozostałe spójniki logiczne, opisuje zależności między dowolnymi stanami rzeczy ${ }^{12}$ i jest spójnikiem funkcjonującym we wszystkich językach współcześnie istniejących, rozwiniętych społeczeństw. Jak zauważa Gernot Böhme ${ }^{13}$, przynależność negacji do każdego języka jest tak oczywista, że zdobycie umiejętności jej wypowiadania wydaje się od razu dane, a nie ontogenetycznie czy filogenetycznie konieczne do zdobycia.

Kluczową rolę negacji postrzega się współcześnie na przykład w tak zwanym „tolerowaniu sprzeczności”, charakterystycznym dla niektórych systemów logiki. Podejście do negacji - jej osłabienie czy inaczej „odebranie właściwej jej stanowczości" prowadzi w niektórych logikach (np. zainicjowanych przez Stanisława Jaśkowskiego) do tolerowania sprzeczności czy nawet wyeliminowania sprzeczności z systemu.

\section{Plaszczyzna czwarta - instytucji społecznych i kulturowych}

\subsection{Sprzeciw instytucjonalny (na przykładzie cywilnego nieposłuszeństwa)}

Instytucja cywilnego/obywatelskiego nieposłuszeństwa (ang. civil disobedience) stanowi przykład celowego działania, służącego złamaniu bądź odstapieniu od przepisów prawnych w imię ugruntowanego przekonania, że wspomniane przepisy w sposób rażący naruszają kluczowe dla łamiących owe przepisy wartości. Sprzeciw czy niezgoda na łamanie w akcie cywilnego nieposłuszeństwa prawa u swych rudymentów wykluczają jednakowoż stosowanie przemocy przez osoby stosujące cywilne nieposłuszeństwo z jednoczesnym wyrażeniem przez nie świadomej zgody na poniesienie konsekwencji prawnych, wynikających ze złamania obowiązujących reguł prawnych. Myśl taką odnajdujemy między innymi w koncepcie prekursora cywilnego nieposłuszeństwa Henry'ego D. Thoreau, jak również w pracach

\footnotetext{
12 E. Żarnecka-Biały, Mała logika, Kraków 1999, s. 38.

13 G. Böhme, dz. cyt., s. 253.
} 
Johna Rawlsa, Charlesa Baya czy Pera Herngrena. Każdy z przywołanych wyżej badaczy zauważa, że cywilne nieposłuszeństwo stanowi przejaw aktywności obywatelskiej, polegającej na publicznym a przy tym otwartym, świadomym i rozmyślnym, jak również demonstracyjnym złamaniu przepisów prawa w celu wyrażenia obywatelskiej niezgody na istnienie tych przepisów. Każdy z wyszczególnionych wyżej myślicieli dodaje jednak zgodnie, że mimo nielegalności czy też bezprawności aktów obywatelskiego nieposłuszeństwa, sprzeciw, jaki one niosą ze sobą, nie może wiązać się z użyciem przemocy, która jest wyjściowo negowana na rzecz akcji bez przemocy. Wśród wspomnianych akcji pozbawionych przemocy wymienić możemy między innymi protestacyjne akcje pokojowe (przejawiające się pod postacią zarówno werbalnych akcji protestacyjnych, w tym pikiet, manifestacji, przemówień, jak również akcji pozawerbalnych, w tym słania petycji, not i listów protestacyjnych, rezygnacji z zajmowanych posad oraz korzyści, jakie piastowane stanowiska za sobą niosą, czy wreszcie radykalnych akcji protestacyjnych, od samookaleczeń poczynając, na samounicestwieniu kończąc), niewspółdziałanie $z$ bezpośrednim adresatem cywilnego nieposłuszeństwa (na płaszczyźnie społecznej: poprzez bojkot, okupację i blokadę instytucji, odmowę współpracy z określonymi strukturami społecznymi, kontrrytualność oraz kontrwyzaniowość, na płaszczyźnie ekonomicznej: przez bojkot produktów ekonomicznych, odmowę płacenia podatków, organizację strajków i wieców protestacyjnych, transfer kapitału czy na przykład rozrost systemu upadłościowego, [jak również] na płaszczyźnie politycznej: poprzez bojkot instytucji władzy, ostracyzm wyborczy, sprzeciw wobec aparatu prawno-politycznego, w tym m.in. sądów czy prokuratury), jak również działalność interwencyjną mającą na celu uwypuklenie i zdemaskowanie przez interwentów przed społeczeństwem zagadnień, które jak dotąd były bądź to przemilczane, bądź też ukrywane, i doprowadzenie do ich ponownego bliższego rozpoznania w drodze debat, moratoriów oraz renegocjacji, których one bezsprzecznie wymagają.

Warto również nadmienić, że sprzeciw obywatelski przejawiający się w akcie cywilnego nieposłuszeństwa musi być poprzedzony namysłem nad motywami leżącymi u podstaw tego aktu. W przeciwnym bowiem razie sprzeciw taki będzie można uznać za niezasadny bądź też fasadowy czy ukrywający się za etykietą cywilnego nieposłuszeństwa, choć w istocie takim niebędący. Żeby bowiem mówić o sprzeciwie obywatelskim przejawiającym się $\mathbf{w}$ akcie cywilnego nieposłuszeństwa, spełnionych powinno być kilka warunków. Po pierwsze, zmiana kontrowersyjnego prawa, mająca za podstawę akt cywilnego nieposłuszeństwa, musi leżeć w interesie 
publicznym, nie zaś w partykularnym interesie jednostkowym. Ponadto prawo, które ów akt chce zmienić, powinno niezbicie łamać elementarne zasady społeczne, prawno-moralne normy postępowania bądź też wartości szczególnie cenione przez społeczeństwo. Jako takie prawo nie może być irracjonalne czy na przykład niespójne. Dopiero po spełnieniu powyższych warunków i przy założeniu, że inne prawne środki reorganizacji czy naprawy wadliwego prawa zawiodły, można sprzeciwić się prawu w akcie cywil-

\section{nego nieposłuszeństwa.}

Bezspornie instytucja obywatelskiego nieposłuszeństwa czy też sprzeciwu odegrała ważką rolę między innymi:

1. W walce o równouprawnienie, której towarzyszyła walka z dyskryminacją rasową. Tej poświęcili się między innymi: sprzeciwiający się rozrostowi niewolnictwa, jak też szykanowaniu Indian amerykańskich Thoreau, walczący o emancypację ludności afroamerykańskiej Martin L. King czy też walczący o zniesienie apartheidu Nelson Mandela. Istotą podjętej walki o zniesienie segregacji rasowej nie było jednakże użycie siły, lecz prowadzenie działań uciążliwych dla państwa, jak odmówienie płacenia podatków oraz odwoływanie się do sumienia, będącego źródłem naturalnej sprawiedliwości, co postulował Thoreau, a także bojkot, strajki okupacyjne, marsze czy też zajmowanie miejsc przeznaczonych dla białych, do czego z kolei nawoływali King czy Mandela.

2. $W$ walce $z$ kolonializmem w Afryce, Azji i Indiach. W przypadku walki z kolonializmem (indyjskim) kluczową rolę odegrał Mahatma Gandhi, który kierując kampanią na rzecz praw chłopów i robotników, wzywał do bojkotu angielskich towarów, jak również nawoływał do porzucenia angielskiego sposobu ubierania się. Metodą walki o niepodległość Indii i sprzeciwu wobec kolonializmu stała się u Gandhiego zasada walki bez przemocy (first, non-violence), ograniczająca się do organizowania akcji wolnych od przemocy, jak w przypadku organizowanych marszy (m.in. „marsz soli” z 1930 roku), demonstracji, pochodów i odmowy współpracy z kolonizatorami. Odmowa czy sprzeciw wobec władz zakładały niewypełnianie angielskich zarządzeń i postanowień, niepłacenie podatków, podejmowanie prac niezgodnych z zaleceniem i pozwoleniem władz, bojkot instytucji państwowych, jak również dowolność miejsca zamieszkania.

$\mathrm{Z}$ końcem lat 70 . i na początku lat 80 . instytucja obywatelskiego nieposłuszeństwa miała z kolei wpływ na: 
1. Powstające ruchy pacyfistyczne, pokojowe i antywojenne, które zaczęły sprzeciwiać się coraz głośniej „wyścigowi zbrojeń”, w szczególności zaczęły występować przeciwko produkcji i rozmieszczaniu broni masowego rażenia w Europie Zachodniej. Wcześniej zaś kontrkultura amerykańska wystapiła przeciwko wojnie w Wietnamie, jak również:

2. rozwój ruchów ekologicznych, które wystapiły przeciwko projektom i planom rządowym oraz praktykom korporacyjnym przyczyniającym się do lawinowej dewastacji środowiska przyrodniczego, w następstwie budowy sieci tam, zapór, autostrad i elektrowni. W Polsce można było zaobserwować w tym okresie między innymi protesty przeciwko budowie elektrowni jądrowej w Żarnowcu, następnie protest przeciwko budowie zapory wodnej na Dunajcu (tzw. „Akcja Tama Tamie”), obronę Parku Krajobrazowego na Górze św. Anny przed budową autostrady, obecnie zaś choćby protesty ekologów przeciwko dewastacji Doliny Rospudy.

Warto przy tym nadmienić, że zarówno sprzeciw ze strony pacyfistów, jak też środowisk ekologów był formą sprzeciwu bez użycia przemocy bezpośredniej i pośredniej. Ograniczał się wyłącznie do demonstrowania i pikietowania projektów, które bezpośrednio kłócą się z wartościami cenionymi przez człowieka, jak życie, zdrowie, wolność, sprawiedliwość czy choćby szacunek dla drugiego. Niewatpliwie instytucja obywatelskiego nieposłuszeństwa wpłynęła na powstawanie innych jeszcze ruchów (by wymienić choćby ruch feministyczny), ale ich omówienie nie stanie się składową i tak rozbudowanego tekstu.

\subsection{Sprzeciw na płaszczyźnie instytucji kulturowych}

Możliwość powiedzenia „nie” objawia się tu w bardzo różnorodny sposób. Może to być na przykład zakwestionowanie lub odrzucenie (np. wzorów i zastanych wartości porządku społecznego), krytyka, bunt (np. bunt młodzieży czy konflikt pokoleń), opozycja (wobec m.in. aparatu władzy), podważenie (np. autorytetu), odmowa (m.in. udziału w zastanej rzeczywistości). Szczególną pozycję pośród zarysowanych wyżej aktów sprzeciwu zdaje się mieć kontestacja.

Jak pisała Aldona Jawłowska w książce Drogi kontrkultury, termin ten ewoluował na przestrzeni lat i zmieniało się jego rozumienie. Źródłowo odnosił się do łacińskiego contestor, contestari, oznaczającego potwierdzenie, 
odwołanie się do świadectwa jakichś wyższych instancji, następnie ewoluował - poprzez francuskie contestation: zakwestionowanie, spór, negacja do rozumienia współczesnego. Przywołując Jawłowską, można powiedzieć, że znaczenie najnowsze jest nawiązaniem do określeń źródłowych. W aktualnych rozumieniach słowa kontestacja coraz wyraźniej występuje podwójność sensu. Zawiera się w nim bowiem zaprzeczenie będące jednocześnie potwierdzeniem wartości, w imieniu których się zaprzecza ${ }^{14}$. Mamy zatem do czynienia z, jak to ujęła Jawłowska, chwiejnością semantyczna, która zawiera w sobie zarówno niszczenie, jak i konstrukcje.

Objawy postaw kontestacyjnych są przy tym bardzo różne. Można wśród nich między innymi wymienić demonstracje, strajki, zamachy czy ucieczki z domu. Ruchy kontestacyjne ściśle wiąże się przede wszystkim z latami 60. w USA, choć nie tylko.

Sprzeciw społeczny zarówno w przeszłości, jak i obecnie często kierował się przeciw instytucjom kultury. W akcjach wymierzonych na przykład przeciw uniwersytetom czy muzeom manifestowało się przekonanie, że instytucje te są $\mathrm{w}$ gruncie rzeczy narzędziami manipulacji.

Jak ekspediowała Jawłowska, niezależnie od orientacji ideologicznej czy narodowości, można zasadniczo wyróżnić trzy wspólne kierunki ataków: na system kształcenia (ponieważ uosabia represję i zinstytucjonalizowanie), na środki masowego przekazu (w swojej funkcji wspierającej i ograniczającej i podporządkowującej aparatowi władzy) i na technikę (przeciw jej dominującej roli na polu kultury). Przyjrzyjmy się niżej dwu wybranym przykładom, gdzie ruchy społeczne uderzały w instytucje kultury.

1. Przeciw uniwersytetom - jednym z obiektów działań ruchów kontestacyjnych stał się system kształcenia. Przekonaniem, które legło u podstaw sprzeciwu skierowanego zwłaszcza przeciwko uniwersytetom, była myśl o nieadekwatności systemu kształcenia w stosunku do potrzeb społecznych. W rozumieniu przeciwników oświaty instytucje kształcenia podważają swoim działaniem główne osiagnięcia naszej cywilizacji, jakim mogło być upowszechnienie oświaty. Ogólnie pojęte szkoły i uniwersytety rozumiane nie są jako dobro, lecz raczej środek represji, miejsce utrzymywania nierówności społecznej. Utożsamiano je z miejscem ogniskowania się krytykowanych sił społecznych. Jako alternatywę postulowano między innymi wizje oparte na społeczeństwie wolnych twórców (m.in. Herbert Marcuze), gdzie nacisk osobistego rozwoju położony byłby na tak

${ }^{14}$ A. Jawłowska, Drogi kontrkultury, Warszawa 1975, s. 7. 
zwanej edukacji „w głąb”, zakładającej „wejrzenie w siebie”, medytację, ćwiczenia zaczerpnięte $\mathrm{z}$ religii wschodu oraz różne formy samokształcenia. Sugerowano w związku z tym szeroko zakrojone zmiany zarówno $\mathrm{w}$ organizacji systemu kształcenia, jak i przekazywanych treści (np. mając za podstawę miłość, którą uznano za jedyną siłę pozwalającą na takie właśnie przekazywanie treści, jak i ich przyswajanie). Podsumowując, można zatem powiedzieć, że kryzys systemu kształcenia idzie tu w parze z podważeniem autorytetu nauki. W intencji jej przeciwników musi dojść do obalenia mitu jej obiektywności. Nauka jest jedynie narzędziem, jedynie instrumentem, który może być użyty bądź to do realizacji tego, co dobre, bądź też do podtrzymywania tego co $z \nmid e^{15} \mathrm{~W}$ świecie prawdziwych i fałszywych wartości, w których żyje człowiek ${ }^{16}$.

2. Ruch Occupy Museum - współcześnie sprzeciw jest jedną z najgłośniejszych w całym ruchu artystycznym form aktywności. Najbardziej obecnie znaną formą sprzeciwu na gruncie instytucji kulturowych jest ruch powiązany z Occupy Wall Street, to jest ruch Occupy Museum, który pierwszą akcję okupacji muzeum zorganizował w październiku 2011 roku. Jak mówił Noan Fischer, założyciel tej grupy: „Muzea są ważną częścią neoliberalnego systemu, przeciw któremu protestuje się na Wall Street. Są one wręcz jego świątynia$\mathrm{mi}$ - reprodukują jego logike, uprzedmiotawiają jego symbole i są od niego finansowo zależne"17. Podobnie jak na Wall Street, najbogatszy 1 procent kontroluje prawie wszystko, oddając się kolekcjonerstwu, wpływając na rynek sztuki, decyduje ostatecznie o karierach poszczególnych artystów. Akcja ruchu Occupy Museum miała przyczynić się wszczęcia dyskusji na zarysowany wyżej problem, propagując przy tym idee ruchu solidarnościowego, to jest pozbawienie hierarchizacji i indywidualizmu. Stawianym często temu ruchowi zarzutem jest jednak to, że właśnie budowanie takiego wizerunku, a nie rzeczywisty dialog jest celem grupy. W praktyce, także zdaniem samych jej organizatorów, okupowanie dla samego faktu okupowania czy stawianie się ponad stawiane konkretne żądania, choć w tle przewija się postulat rozpoczęcia szeroko zakrojonych rozmów na temat między innymi znaczenia pieniędzy czy władzy

\footnotetext{
15 Tamże, s. 169.

16 Tamże, s. 170.

17 N. Fischer, Okupuj pobliskie muzeum!, „Krytyka Polityczna” 30 (2011), s. 40.
} 
w świecie sztuki, jest niezasadne. Swoistym aktem autorefleksji nurtu było umieszczenie w przestrzeniach wystawienniczych Biennale w Berlinie 2012 miasteczka oburzonych, gdzie to sam ruch stał się aktem godnym artystycznej uwagi.

\section{Plaszczyzna piąta - ducha}

Roman Ingarden płaszczyznę ducha i jej dopełnienie, rozumiane jako świat kultury, przejmująco opisuje jako tę, dzięki której życie człowieka „,zaczyna mieć jakieś zadanie i cel i nabywa pewnego sensu i znaczenia, którego by nie miało w samej pierwotnej Naturze"18. Cała dziedzina świata kultury, w tym dzieła sztuki, nauka, filozofia, religia, historia samych siebie i ludzkości, wyrastają w gruncie rzeczy z niezgody na bezwarunkową przynależność do świata przyrody ${ }^{19}$. Choć to nie zmienia faktu, że i tak stanowi ona podłoże całej rzeczywistości - także tej nowej ${ }^{20}$. Wysiłek stworzenia świata kultury można rozumieć jako chęć jej zanegowania, wyrośnięcia ponad nią. W tym świecie - duchowym, człowiek się rozpoznaje i z tym światem człowiek się identyfikuje. Dochodzi tu do realizacji sprzeciwu, który jest wspomnianą „niezgodą" na całkowitą przynależność do świata przyrody. Absolutne zanegowanie jest jednak oczywiście niemożliwe i w tym, jak podkreśla Ingarden, leży istota człowieka oraz jego tragizm.

W odwołaniu na przykład do dziedziny sztuki, w której duch się realizuje, można wymienić kilka aspektów manifestowania się sprzeciwu. Jak konstytutywnym dla współczesnego rozumienia samej sztuki pojęciem jest sprzeciw/bunt, pokazała między innymi wystawa i książka przygotowane na jubileusz stulecia Akademii Sztuk Pięknych w Warszawie w roku 2004. Pedagodzy i kuratorzy właśnie wokół takich pojęć, jak powinność i bunt, zdecydowali się uporządkować artystyczny i intelektualny dorobek uczelni. $\mathrm{Na}$ wstępie zaproponowali kilka par kategorii frondalnych wywiedzionych z podstawowej opozycji, jaka występuje między powyższymi terminami, by następnie przejść do dalszych szczegółowych już opozycji, w tym ta-

18 R. Ingarden, Ksiqżeczka o człowieku, Kraków 1987, s. 15.

19 Podkreślić jednocześnie należy, że to, co zostało w tym miejscu zaanonsowane jako zagrażające jednostce, znajduje się nie tylko na zewnątrz jej, ale i wewnątrz (jak choćby popędy). Stąd możliwe są interpretacje kultury jako wyrazu niezgody na to wszystko, co zagraża człowiekowi zarówno z zewnątrz, jak i z (jego) wewnątrz.

${ }^{20}$ Patrz: R. Ingarden, Człowiek i jego rzeczywistość, w: tenże, Ksią̇eczka o człowieku. 
kich jak ,powinność wobec państwa, narodu/anarchizm, powinność wobec sztuki (doskonałość)/spontaniczność, tradycja akademicka/innowacyjność, instytucja/środowisko, klasyka/nowatorstwo, postawa państwowotwórcza/ /postawa kontestująca, ojczyzna/gombrowiczowska «synczyzna», harmonia/kultywowanie chaosu"21.

Dla zastosowanej wyżej podstawowej opozycji, to jest powinność/bunt, charakterystyczne jest niewątpliwie to, że oba pojęcia posiadają konotację pozytywną. Można powiedzieć, że uzupełniają się w praktyce artystycznej. Charakterystyczne napięcie, które między nimi powstaje, implikuje pytania o między innymi miejsce artysty w społeczeństwie, wolność sztuki czy choćby odpowiedzialność twórcy. Upatruje się w nim istoty twórczego niepokoju. Można powiedzieć, że dzięki napięciu wyrażającemu się w „buncie przeciw temu, co zastane", to jest temu, co zdążyło stać się już wzorcem czy też stereotypem, dochodzi się do poszukiwania nowych koncepcji. To ono, jak podkreślają twórcy, dowodzi, że środowisko jest żywe.

\section{Podsumowanie. Tożsamość wywiedziona ze sprzeciwu}

Jak wynika z dokonanej powyżej wstępnej charakterystyki objawiania się sprzeciwu na wszystkich płaszczyznach bycia człowieka, jednostkę można próbować charakteryzować jako istotę, którą wyróżnia i określa możliwość powiedzenia „nie”. Wydaje się, że taki model „przejawiania się” jednostki nie jest niczym nowym, albowiem istnieje już na przykład w przekazie mitycznym.

Za kulturowy wzór buntownika można uznać mitycznego Prometeusza, który swoją postawą wyraża niezgodę na otaczająca go rzeczywistość. Buntownik-outsider to także bohater kontrkultury. Ciekawym tropem wydaje się poszukiwanie związków występujących pomiędzy wspomnianym outsiderem a modnym zwłaszcza na przełomie XIX i XX stulecia wzorem dekadenta. Wszechstronna możliwość negacji może być bowiem traktowana jako współczesna figura duchowości człowieka, która najpełniej wyraża również jego kryzysową świadomość. Jak zauważa w swojej książce Inna nowoczesność. Pytanie o współczesna figurę duchowości Agata Bielik-Robson, „chcenie”, które Autorka utożsamia z „wolą” i w świetle której interpretuje podstawową zasadę nowoczesności (cogito) rozczarowało się. Trzeba powiedzieć, że projekt ten poniósł klęskę i z „woli”, i z „chcenia” przeszedł

${ }^{21}$ Powinność i bunt, Warszawa 2004, s. 10. 
w „niechcenie”. Wcześniejszy entuzjazm i zaangażowanie nabrało tonu nihilistycznego. Podejście takie rysuje tym niemniej nową, ciekawą perspektywę poznawczą dla dalszych, pogłębionych badań nad kategorią sprzeciwu.

\section{On the Issue of Opposition: Introduction to the Subject - Typology of Definition - Range of Influence (Summary)}

This text addresses the issue of opposition, which is currently widely discussed in science and beyond, showing itself on five different planes of being a human such as: natural things and processes, mental experiences, objective counterparts, social and cultural institutions, as well as on the plane of spirit. It is also worth noting that although the word has several synonyms like resist, do not agree to, defy, refuse or protest; eventually, identifying opposition with these words reduces the meaning of opposition as will be shown in this article. However, the synonymous understanding of opposition will understandably change depending on the choice of the plane and it will also be discussed here. In addition to the introduction to the issue of opposition and its typology, a wide range of influence of the definition of opposition in relation to the practical references will be highlighted.

Keywords: opposition, plane of natural things and processes, plane of mental experiences, plane of objective counterparts, plane of social and cultural institutions, plane of spirit, identity

\section{Wokól zagadnienia sprzeciwu. Wstępne rozpoznanie tematu - typologia pojęcia - zakres oddziaływania (Streszczenie)}

W tekście omówiono szeroko dziś dyskutowane, zarówno w nauce, jak i poza nią, zagadnienie sprzeciwu przejawiającego się na pięciu płaszczyznach bycia człowiekiem, to jest: rzeczy i procesów naturalnych, przeżyć psychicznych, obiektywnych odpowiedników, instytucji społecznych $i$ kulturowych, jak też na płaszczyźnie ducha. Warto przy tym dodać, że chociaż termin sprzeciwu posiada liczne określenia bliskoznaczne, jak choćby opierać się, nie godzić się na, przeciwstawiać się, wzbraniać się, oponować czy choćby protestować, to ostatecznie, co zostanie pokazane w artykule, nie są one tym samym, ich utożsamienie zaś niewątpliwie spłyca znaczenie kategorii sprzeciwu. Tym niemniej nie sposób nie zauważyć, że w zależności od wyboru płaszczyzny, na której dyskutuje się kategorię sprzeciwu, zmieniać bę- 
dzie się jego synonimiczne pojmowanie, co również zostanie wykazane w tekście. Oprócz wstępnego nakreślenia zagadnienia sprzeciwu, jak też typologii wspomnianego pojęcia, w pracy zostanie ukazany szeroki zakres oddziaływania pojęcia sprzeciwu w ramach praktycznych odniesień.

Słowa kluczowe: sprzeciw, płaszczyzna rzeczy i procesów naturalnych, płaszczyzna przeżyć psychicznych, płaszczyzna obiektywnych odpowiedników, płaszczyzna instytucji społecznych i kulturowych, płaszczyzna ducha, tożsamość 